\title{
EFFECT OF MARKETING EFFICIENCY IMPROVEMENT IN INDONESIA
}

\author{
Ratya Anindita, Nur Baladina, Budi Setiawan, Researchers \\ Department of Socio-Economics, University of Brawijaya, Indonesia \\ Email: ratyaa@ub.ac.id
}

\begin{abstract}
This paper studies the effect of marketing efficiency in Indonesia. If the government could improve the marketing efficiency may result to an improvement on food security and household welfare. This analysis used a computable general equilibrium model where households disaggregated by eight income class based on Indonesian SAM year 2008 with 23 sectors. The results showed that the improvement of marketing efficiency by $5-15 \%$ could increase the supply of domestic agricultural by 9.7 to $200 \%$, except nuts which remained constant, while the other sectors would be vary. Exporting from agricultural sectors increased by $120-1287 \%$, but the rice and other crops would declined, the other sectors rose and constant. The imports quantities of agricultural sector generally rose, except the corn are remained constant, tubers are decline. Meanwhile the quantity import of other sectors would rose. Improvement of agricultural marketing efficiency also resulted in a decrease in household's expenses by 3.3 to $6.7 \%, 41-45 \%$ and government by 3.9 to $7.3 \%$. As a contra, the welfare of households rose from 0.7 to $1.1 \%$ and the producer dropped $38-40 \%$. Thus improving marketing efficiency of agricultural products have a positive effect on increasing food security and household welfare in Indonesia.
\end{abstract}

\section{KEY WORDS}

Marketing efficiency improvement; Output domestic; Export; Import; Food security; Household welfare; Computable general equilibrium.

Indonesia's economic growth has increased significantly since 1970's. In 1979-1980, the average economic growth in Indonesia is $4.5 \%$ per year, then continued to increase by $7 \%$ during time period $1989-1993$ and $7.9 \%$ within 1994-1996 (Siregar and Wahyuniarti, 2007). During economic crisis in 1997, the economic growth decline by $-4.7 \%$ and getting worst in 1998 by $-13.1 \%$. However in 1999 , the economic tend to increase by $4-5 \%$ per year. In averaged the national economic growth from 1984 to 2007 is $4.9 \%$ per year. Meanwhile, the economic growth in the agricultural sector also increased smoothly. In the period 1984 2007 , the average economic growth of the agricultural sector was only $2.8 \%$ per year, compare with other sector which increase in the higher magnitude. Therefore, the role of the agricultural sector to the gross domestic product (GDP) has declined from 51\% in 1965 to $17 \%$ in 2005 (Central Bureau of Statistics, 2010).

According to the 1983 constant prices, the farmer's exchange rate shows declining trend. During 1986-2007 period, the highest farmer's exchange rate is 109.27 in 1988 and the lowest is 95.25 in 1993 (Central Bureau of Statistics, 2010). The decline in the exchange rate trend shows that the farmer's welfare declined due to the slow rising in price compared to the non-agricultural products. The inability of the farmers in the marketing of agricultural products caused farmers selling price is low. This is consistent with Schultz (1964) who state that in the context of traditional agriculture has occurred long-term economic equilibrium in the agricultural sector due to constant technological, while farmer's preference and motives while have not changed. This resulted in marginalized of agricultural sector in rural areas since they are in a condition which not capable to change their economic conditions, thus the improvement in applied technology and recommendations will help them to solve poverty.

The stagnancy in prices is also caused by the unchanged in markets growth, which turn poverty in rural areas worst (Janvry, 1975). Stagnant conditions in the agricultural sector are also exacerbated by the import substitution policy and overvalued exchange rate which creates a low agricultural prices. Furthermore, farmers/producers are reluctant to participate in marketing activities and value-added process (post-harvest processing), which caused the income of farmers is still highly depend on the price specified by the trader and / or 
processor. According to Downey and Erickson (2002), in the agricultural sector, the advantage of farming/cultivation is only $30 \%$, while $70 \%$ of them are in the downstream (processing and marketing). In addition, an agricultural market faced by farmers is imperfect competition market which tend to oligopsony and monopsony market. This condition results in the exploitation by the monopsonist affect by the existence of market power gap in the market, which puts the position of farmer's price relatively stagnant. Therefore, it is necessary to improve the farmer's exchange rate through marketing efficiency improvement.

In the agriculture development, marketing efficiency improvement of agriculture product has an important role, such as (1) increasing the activity specialization in the comparative advantage in order to support the national trade activity; (2) increasing the efficiency and the national resource commerce; and (3) the advancement in the marketing sector will stimulate the economic growth (Smalley and Ehui, 1995). Hayami (2001) also state that efficient market and marketing efficiency have an important implication toward economic development policy, especially in the agriculture sector. In the efficient market, government interventions are needed through the development of information system and an efficient infrastructure to support the marketing system from the rural area to the final consumer. With a reliable information system, the information of price and product will be easier to access by the producer and consumer. At the end, the perfect information will enable to decrease marketing margin, increase the selling price in the level of producer, and decrease the purchasing price in the level of consumer.

According to Mellor (1967), the size of marketing margin will have a direct effect on the producer price which referred to marketing efficiency improvements. The effect of marketing efficiency improvement will indirectly decrease the consumer price. Thus, the increasing in marketing efficiency will caused the decreasing of retail price which stimulate the total demand, and finally stimulate the increasing of producer price. In the same time, the increasing of producer price will improve price efficiency in the level of middleman so that the production cost can be reduced. Price in the level of consumer will influence the total demand of the commodities regarding the elasticity or the responsiveness of those commodities to the change in price (Landes and Burfisher, 2009).

Marketing efficiency improvement can be achieve through the improving of farmer's role to take a part in the marketing activity, such as improving price information system, develop the wholesale and auction market for agricultural products, and improve the transportation facilities. Through the marketing efficiency improvement policy, farmer price expected to increase, while the consumer price can be reduce. When the price stability can be achieved, it will stimulate the increasing of consumption and production of agriculture commodity. Furthermore, the marketing efficiency improvement will support the availability and accessibility of food, which related to the food absorption to strengthen the community's economy. This program is important to achieve, since the food security cannot be interpreted narrowly only to increase production to achieve availability/ food self-sufficiency.

According to Weingartner (2004), food availability, food access, food utilization, and food stability, while nutritional status is the outcome of the food security. Availability, access, absorption, and stability of food is an integral sub-systems that must be met in unity. If one of the subsystems are not met, the national food security is not perfectly achieve. Borton and Shoham (1991) suggested that the availability of food at the national level does not automatically ensure the food security at the household level. Therefore, it is necessary to study which examines the significant of marketing efficiency improvement effect to the national food security and household welfare.

\section{METHODOLOGY}

One of the difficulties to measure effect of marketing policy in Indonesia is the effect on economic growth. In 1999, Arndt et al. firstly introduce a method to measure effect of marketing improvement on the economic growth through CGE (Computable General Equilibrium) model in Mozambique. Landes dan Burfisher (2009) deeply investigated the comprehensive effect on the India's economic growth. CGE model is a comprehensive 
approach that encapsulates multimarket models and uses the market equilibrium as its fundamental element analysis (Markusen, 2005). CGE model describing the economic agents and their behavior in the market, thus its enable to summarized the different markets into a general equilibrium. The formulation of CGE models include linkages between economic actors, ie companies or industries, households, investors, governments, importers, exporters and a linkage between different commodity markets.

CGE model has advantages in revealing the effect of production, consumption, trade, investment and spatial interaction affect by policy or shock. This model has been applied to simulate the socio-economic effect of a given scenario. First, the foreign shock such as changes in the terms of trade (e.g. the increasing price of imported oil or decreasing price of main export commodity in one country). Second, changes in economic policies, such as taxes and subsidies in the trade. Third, changes in the social structure of the domestic economy, such as changes in agricultural technology, the redistribution of assets and human capital formation (Sadoulet and de Janvry, 1995).

CGE models developed in this study is to introduce the marketing margin in the economy model, to identify the influence of marketing margin activity to the import and export activity, and domestic marketing, which is further will influence the performance of economy sectoral and food security and household welfare. This model follow developed by Pudjiastuti et al. (2013). To achieve the research goal, the static CGE model was used with the constant return to scale assumption, as a reference by Soudolet and Janvry (1995) dan Lofgren et al. (2002). This model is more appropriate to identity the effects of the policy. In addition, this model is also built using MPSGE approach. By using MPSGE, calibration can be performed simultaneously (Markusen, 2005).

The data used in this study is a secondary data derived from the Social Accounting Matrix (SAM) Indonesia and Indonesia Annual Input Output Table (IO) in 2008. Disagregation and elimination any negative element in the data was done and continued with the data mapping, built model, and executing the static CGE model by using GAMS/MPSGE. Analysis continued with calibrated and validated by using Indonesian SAM data which already modified to obtain research parameter, while the other parameter such as Armington elasticity, the elasticity of primer production factor, and substitution elasticity are obtain from the earlier research.

The model is divided into 23 sectors and 3 primary factors, namely capital and labor (skilled and unskilled) which have mobile characteristic. Intermediate inputs used in the production process in each group classified into two categories according to the input source such as domestic and imported intermediate inputs. While the agricultural sector in this paper is distinguished for understanding agriculture in a narrow sense: (1) food crops that divide into sub-sectors of rice, beans, corn, root crops, vegetables and fruits, and other food crop commodity, (2) the other agricultural commodity. The household term in this model is divided into 8 groups. Several simulations policies applied include: (a) improving marketing efficiency by $5 \%$, (b) improving marketing efficiency by $8 \%$, (c) improving marketing efficiency by $10 \%$, and (d) improving marketing efficiency by $15 \%$.

\section{RESULTS AND DISCUSSION}

The empirical result showed that marketing efficiency improvement of agricultural have a positive effect on food security indicators. It can be seen from the change in quantity of domestic output, exports and imports, as presented below.

Effects on Domestic Output. Table 1 shows that the marketing efficiency improvement of agricultural products by $5-15 \%$ enable to increase the domestic output in almost all sectors, except fertilizers and pesticides industry which fell from 7.9 to $8.4 \%$. Besides that, the domestic output of nuts are remain constant. These results are consistent with the theory of Mellor (1967) and Smalley and Ehui (1995), whose state that the improvement of marketing efficiency will stimulate the economic growth by reduced marketing margins, which in turn leading to higher selling prices and furthermore will encourage producers to increase the production output. For food crops, the quantity output of 
rice increase from 113 to $159 \%$ due to the improvement of marketing efficiency, which is expected to support the rice self-sufficiency program launched by the Government of Indonesia in 2014.

Meanwhile, the increase in agricultural output quantities such as vegetables and fruits as a source of vitamins and minerals (28-33\%), other food (100-200\%), other crops (9-13\%), livestock as a source of animal protein (57-74\%), forestry and hunting (1-2\%), and fishery as a source of protein and omega-3 (120-123\%). This result indicated that the availability and diversity of food, which is the major sub-system of food security (Weingartner, 2004) are stronger achieve in Indonesia. Furthermore, the increasing output quantities of food and beverage industry by $12-17 \%$, suspected as effect of the increasing quantity of food crops and other food commodity, such as vegetables and fruits, livestock, forestry and hunting, and fishery, which is at the end increases the output of the food and beverage industry as a downstream of the fresh agricultural products. Mapfumo et al. (2012) claimed that the agricultural sector plays an important role in economic growth.

Table 1 - Changes in Domestic Output Quantity

\begin{tabular}{|c|c|c|c|c|c|}
\hline \multirow{2}{*}{ Sector } & \multirow{2}{*}{ Baseline (Billion IDR) } & \multicolumn{4}{|c|}{ The effect of Marketing Efficiency Improvement (\%) } \\
\hline & & $5 \%$ & $8 \%$ & $10 \%$ & $15 \%$ \\
\hline Rice & 216 & 113,89 & 159,72 & 159,72 & 159,72 \\
\hline Bean & 38 & 0 & 0 & 0 & 0 \\
\hline Corn & 109 & 38,53 & 47,71 & 47,71 & 47,71 \\
\hline Root crop & 24 & 70,83 & 66,67 & 66,67 & 66,67 \\
\hline Vegetable and Fruit & 513 & 28,27 & 33,72 & 33,53 & 33,53 \\
\hline Other crops & 2 & 200 & 100 & 100 & 100 \\
\hline Other plant & 1.303 & 9,67 & 13,43 & 13,43 & 13,43 \\
\hline Livestock & 531 & 57,25 & 74,2 & 74,2 & 74,58 \\
\hline Forestry and Hunting & 133 & 1,5 & 2,26 & 2,26 & 2,26 \\
\hline Fishery & 338 & 120,12 & 122,78 & 123,08 & 123,08 \\
\hline Food and Beverage industry & 6.315 & 12,16 & 17,34 & 17,56 & 17,66 \\
\hline Fertilizer and pesticide industry & 215 & $-7,91$ & $-8,37$ & $-8,37$ & $-8,37$ \\
\hline Other Industry & 28.113 & 32,63 & 55,02 & 55,02 & 54,99 \\
\hline Service & 5538 & 7,75 & 13,87 & 13,87 & 13,87 \\
\hline
\end{tabular}

Source: Empirical Result of the Simulation Analysis, 2012.

However, the increased output of food crops, vegetables and fruits, and other crops are not supported by fertilizers and pesticides industry. It is suspected as effect of the decreasing output of fertilizers and pesticides industry. Furthermore the quantity output of bean are remain constant because by the characteristic of the bean which can't compete in terms of land use with food crops, vegetables and fruits, and other crops. This commodities generally grown in the paddy field and dry land which is also the area of food crops, vegetables and fruits, as well as other crops, so that when the marketing efficiency improved, and stimulate the increasing in price and output, the change in a been commodity will occur lately.

Marketing efficiency improvements enable to stimulate the increasing of domestic output quantity of other industrial sectors by $32-55 \%$ and services sector by $7-14 \%$. This information support the statement that any policy to develop and improve the performance of agriculture sector, including marketing efficiency improvement to the agriculture product, will positively effects on the performance of forward and backward linkage sectors with the agriculture sector.

Effects on Export Quantity. Table 2 present the effect of the marketing efficiency improvement to the export quantity. According to table 2, the improvement strategy increased the export quantities in almost all sectors by $5-15 \%$, except paddy and other crops which decreased. Besides the decreasing in paddy subsector, the export quantity of fertilizers and pesticides industry remain constant. Paddy and other crops sectors currently not exported because it still has not been able to meet the domestic needs. The decreasing of export quantity during marketing efficiency improvement was expected, since the domestic 
demand couldn't satisfy yet. Furthermore, the rapid growth of the population also influences the increasing demand of rice and other crop commodity. One of the effects of the marketing efficiency improvement is the increasing of the purchasing power of the domestic consumer. Therefore although the quantity of paddy and other agricultural crop are increase, it will be prioritized to sell in the domestic market.

The export quantity of fertilizers and pesticides industry are constant in the level of 2 billion IDR, because it still not able to meet the domestic needs. Moreover, the domestic output of fertilizer and pesticide industry declined from 7.9 to $8.4 \%$ from a baseline of 215 billion IDR after the implementation of marketing efficiency improvements. Therefore the domestic output of fertilizer and pesticide industries has been sold out in the domestic market without need to be exported.

The improvement of agricultural marketing efficiency by $5-15 \%$ enables to increase the export quantity of crop commodity. The increasing of exports quantity is $126-143 \%$ for beans, $186-197 \%$ for corn, and $1287 \%$ for tubers. Mellor (1967) and Smalley and Ehui (1995) states that improved marketing efficiency leading to higher selling prices at the producer level so that producers respond by increasing production output. However most of the populations still have a high dependence on the paddy (rice) consumption of paddy, thus the increasing quantity of food crops (except paddy) not absorbed in the domestic market and had to export.

Table 2 - Changes in Export Quantity

\begin{tabular}{|c|c|c|c|c|c|}
\hline \multirow{2}{*}{ Sector } & \multirow{2}{*}{ Baseline (Billion IDR) } & \multicolumn{4}{|c|}{ The effect of Marketing Efficiency Improvement (\%) } \\
\hline & & $5 \%$ & $8 \%$ & $10 \%$ & $15 \%$ \\
\hline Rice & 0,001 & -100 & -100 & -100 & -100 \\
\hline Bean & 0,043 & 125,93 & 142,04 & 143,04 & 143,04 \\
\hline Corn & 0,201 & 185,62 & 196,83 & 197,4 & 197,51 \\
\hline Root crop & 0,072 & $1.286,96$ & $1.286,96$ & $1.286,96$ & $1.286,96$ \\
\hline Vegetable and Fruit & 0,382 & 120,44 & 129,94 & 130,18 & 130,18 \\
\hline Other crops & 0,053 & 298,34 & 399,48 & 418,43 & 418,97 \\
\hline Other plant & 13 & $-53,85$ & $-61,54$ & $-61,54$ & $-61,54$ \\
\hline Livestock & 0,494 & 102,56 & 102,56 & 102,56 & 102,56 \\
\hline Forestry and Hunting & 0,474 & 6,67 & 5,13 & 5,24 & 5,24 \\
\hline Fishery & 4 & 175 & 200 & 200 & 200 \\
\hline Food and Beverage industry & 1.145 & 20,7 & 24,37 & 24,37 & 24,37 \\
\hline Fertilizer and pesticide industry & 2 & 0 & 0 & 0 & 0 \\
\hline Other Industry & 4.346 & 72,5 & 96,225 & 96,23 & 96,23 \\
\hline Service & 55,929 & 56,2 & 67 & 67 & 67 \\
\hline
\end{tabular}

Source: Empirical Result of the Simulation Analysis, 2012.

Meanwhile, the increasing quantity of exports for some sectors, such as vegetables and fruits as a source of vitamins and minerals (120-130\%), other food (298-399\%), livestock as a source of animal protein (102.56\%), forestry and hunting (5 to 6.7\%), fisheries as a source of protein and omega-3 (175-200\%), as well as food and beverage industry $(20-24 \%)$ assumed because most of the market are under excess condition. The declining of the purchasing power of domestic consumer caused the decreasing of domestic consumption toward secondary food product, such as vegetables, and fruit. Therefore the excess supply of those commodities distributed to the international market. This information indicates that food security in Indonesia is still fragile since the availability of nutritious food (food availability) and the diversity of food (food diversification) in the form of an increase in domestic output quantities such as fruits and vegetables, other foodstuffs, livestock, forestry and hunting, fishery, as well as the food and beverage industry is not followed by optimal access (food access) and absorption of food (food utilization).

Marketing efficiency improvement by $5-15 \%$ also enable to push the increasing of export quantity of other industrial sectors (72-96\%) and services sector (56-67\%). This information indicates that the marketing efficiency improvement can lower the retail price. Further, it can rise the number of export demand and lead the increasing in export prices at 
the producer level. Manufacturers will respond to this situation by increasing the quantity of export supply. This means improving the marketing efficiency can enhance the comparative advantage, so that Indonesia can increase its competitiveness in world markets.

Effects on Import Quantity. The result of the simulation which presented in Table 3 shows that improving marketing efficiency of agricultural product by $5-15 \%$ enable to increase the import quantity in almost all sectors, except corn, root crops, forestry and hunting, fishery, and fertilizer and pesticides industry. The constant quantity of corn, fertilizer and pesticide industry indicate that those sub-sector still couldn't satisfy the domestic needs. Therefore, the import quantity remains constant. The tubers crops, forestry and hunting, and fishery sector suffer a declining in imports quantities by 4.9 to $21.2 \%$ due to the increasing in the domestic production and had been able to satisfy most of the domestic demand.

For the crops sector, marketing efficiency improvements by $5-15 \%$ enable to increase the quantity of rice imports $(11.9 \%)$ and beans (3.4 to $6.9 \%)$. The quantity of imported rice has increased to fulfill domestic needs, which is still a deficit. While the increase in the quantity of imported been, suspected because there are several classes of domestic consumers who want to consume a high-quality nuts at competitive prices. Therefore, the quantity of imports experienced a slight improvement although domestic production remained unchanged in the base line 38 billion IDR, while the export quantity has increased significantly (from 125.93 to $143.04 \%$ ) from the base line 43 billion IDR.

The improvement of marketing efficiency of agriculture product by $5-15 \%$ also increase the imports quantity of vegetable and fruit $(7-14 \%)$, other crops commodity $(104-261 \%)$, other plant commodity $(68-100 \%)$, livestock $(62-100 \%)$, food and beverage industry $(43-52 \%)$, other industry (13-22\%), and services (21-33\%). The increasing in import quantity not only due to fulfill the domestic demand but also caused by the low quality and competitiveness of the domestic product.

It is characterized by the different price between domestic and import commodity, where the domestic commodity prices are relatively higher than the imported commodities, whereas the quality of the domestic product is relatively lower than the imported commodities. However, higher price of the domestic commodity for long term will encourage domestic producers to increase output so that the quantity of imports will fall.

Table 3 - Changes in Import Quantity

\begin{tabular}{|c|c|c|c|c|c|}
\hline \multirow{2}{*}{ Sector } & \multirow{2}{*}{ Baseline (Billion IDR) } & \multicolumn{4}{|c|}{ The effect of Marketing Efficiency Improvement (\%) } \\
\hline & & $5 \%$ & $8 \%$ & $10 \%$ & $15 \%$ \\
\hline Rice & 0,018 & 11,91 & 11,91 & 11,91 & 11,91 \\
\hline Bean & 29 & 3,45 & 6,9 & 6,9 & 6,9 \\
\hline Corn & 1 & 0 & 0 & 0 & 0 \\
\hline Root crop & 0,191 & $-15,17$ & $-21,2$ & $-21,2$ & $-21,2$ \\
\hline Vegetable and Fruit & 14 & 7,14 & 14,29 & 14,29 & 14,29 \\
\hline Other crops & 26 & 261,54 & 103,85 & 107,69 & 107,69 \\
\hline Other plant & 54 & 68,52 & 100 & 100 & 100 \\
\hline Livestock & 8 & 62,5 & 100 & 100 & 100 \\
\hline Forestry and Hunting & 0,821 & $-4,86$ & $-5,98$ & $-5,98$ & $-5,98$ \\
\hline Fishery & 0,33 & $-11,37$ & $-16,75$ & $-16,75$ & $-16,82$ \\
\hline Food and Beverage industry & 173 & 43,35 & 51,45 & 52,02 & 52,02 \\
\hline Fertilizer and pesticide industry & 100 & 0 & 0 & 0 & 0 \\
\hline Other Industry & 7.501 & 13,36 & 22,19 & 22,19 & 22,19 \\
\hline Service & 145 & 21,12 & 32,92 & 32,92 & 32,92 \\
\hline
\end{tabular}

Source: Empirical Result of the Simulation Analysis, 2012.

Effects on Household Expenditure. The finding shows that marketing efficiency improvement by $5-15 \%$ affect the declining in real expenditure of all economic agents, including households, firms and governments (Table 4). When marketing efficiency improved by $5 \%$, the real expenditure of both farmer and non-farmer households in the village and in the city will decline by 3.31 to $3.41 \%$. The declining of household real expenditure occur in all simulation such as: $6,56-6,66 \%$ decline by $8 \%$ improvement; 6.62 to $6.72 \%$ decline by $10 \%$ 
improvement; and 6.64 to $6.74 \%$ decline by $15 \%$ improvement. This pattern shows that, the greater the marketing efficiency improvement, the smaller household real expenditure.

For the developing countries as Indonesia, where the majority of household income is used to buy the main food, marketing efficiency improved policy will effects consumer directly. The improving in marketing efficiency will reduce transportation cost and marketing margin, which resulted in decreasing of retail price. Since the retail price of main food decrease, the consumer real expenditure will be smaller.

Table 4 - Changes in Household Expenditure

\begin{tabular}{|c|c|c|c|c|c|}
\hline \multirow{2}{*}{ Household } & \multirow{2}{*}{ Baseline (Billion IDR) } & \multicolumn{4}{|c|}{ The effect of marketing efficiency improvement $(\%)$} \\
\hline & & $5 \%$ & $8 \%$ & $10 \%$ & $15 \%$ \\
\hline Farm workers household & 5.188 & $-3,392$ & $-6,65$ & $-6,708$ & $-6,727$ \\
\hline Farmer household employers & 5.252 & $-3,408$ & $-6,664$ & $-6,721$ & $-6,74$ \\
\hline Low income household in rural & 5.165 & $-3,369$ & $-6,621$ & $-6,68$ & $-6,718$ \\
\hline Non-labor force household in rural & 4.869 & $-3,348$ & $-6,593$ & $-6,654$ & $-6,675$ \\
\hline High income household in rural & 4.805 & $-3,309$ & $-6,556$ & $-6,618$ & $-6,639$ \\
\hline Low income household in urban & 5.106 & $-3,369$ & $-6,62$ & $-6,678$ & $-6,718$ \\
\hline Non-labor force household in urban & 4.859 & $-3,369$ & $-6,586$ & $-6,627$ & $-6,668$ \\
\hline High income household in urban & 4.838 & $-3,328$ & $-6,573$ & $-6,635$ & $-6,656$ \\
\hline Firms & 12.444 & $-40,654$ & $-42,784$ & $-44,744$ & $-44,777$ \\
\hline Government & 4.782 & $-3,931$ & $-7,256$ & $-7,319$ & $-7,34$ \\
\hline
\end{tabular}

Source: Empirical Result of the Simulation Analysis, 2012.

The similar trend also occurred in firms and government. The improvement of marketing efficiency by $5-15 \%$ caused the declining in real expenditure by $40.6-44.8 \%$ for manufacturers, and 3.9 to $7.3 \%$ for government. Thus, the greater the efficiency improvement occurred, the lowered real producers and government expenditure. The effect of marketing efficiency improvement toward household expenditure also experience by producer and government, where the improvement policy will decline the marketing margin, which resulted in decreasing retailer price and increasing in purchasing power. According to the declining percentage, producer/manufacturers are the economic actors with the greatest benefit regarding to the improvement of the marketing efficiency of agricultural product.

Effects on Household Welfare. The improving in marketing efficiency of the agriculture product resulted in increasing of household welfare, but decreasing in producer welfare (Table 5). When marketing efficiency improved by $5 \%$, the farmer household welfare increase by 0.85 to $0.86 \%$, non-farmer household welfare increase by $0.70-0.92 \%$, and producer welfare decrease by $38.15 \%$. When marketing efficiency improved by $8-15 \%$, nonfarmer household welfare in the village increase by 0.86 to $1.12 \%$, non-farmer household welfare in the city increase by 0.88 to $1.10 \%$, and producer welfare decrease by 38.15 $4023 \%$. Based on the finding that, the greater marketing efficiency improvements, the greater household welfare. However, as a contra the increasing in marketing efficiency will effect in declining producer welfare.

Table 5 - Changes in Household Welfare

\begin{tabular}{|c|c|c|c|c|c|}
\hline \multirow{2}{*}{ Household } & \multirow{2}{*}{ Baseline (Billion IDR) } & \multicolumn{4}{|c|}{ Effect of Marketing efficiency improvement (\%) } \\
\hline & & $5 \%$ & $8 \%$ & $10 \%$ & $15 \%$ \\
\hline Farm workers household & 580 & 0,8621 & 1,0345 & 0,8621 & 0,8621 \\
\hline Agricultural household employers & 587 & 0,8518 & 1,0221 & 1,0221 & 1,0221 \\
\hline Low income household in rural & 578 & 0,692 & 0,8651 & 0,8651 & 0,8651 \\
\hline Non-labor force household in rural & 545 & 0,7339 & 0,9174 & 0,9174 & 0,9174 \\
\hline High income household in rural & 537 & 0,9311 & 1,1173 & 1,1173 & 1,1173 \\
\hline Low income household in urban & 571 & 0,7005 & 0,8757 & 0,8757 & 0,8757 \\
\hline Non-labor force household in urban & 543 & 0,9208 & 1,105 & 1,105 & 1,105 \\
\hline High income household in urban & 541 & 0,7394 & 0,9242 & 0,9242 & 0,9242 \\
\hline Firms & 1.392 & $-38,147$ & $-38,147$ & $-40,23$ & $-40,23$ \\
\hline
\end{tabular}

Source: Empirical Result of the Simulation Analysis, 2012. 
The declining of producer's welfare commonly caused by the increasing of production costs such as labor wages and input prices for both domestic and imported intermediate inputs. Therefore, the policy of improving marketing efficiency of agricultural product will not bring a positive effect on producers if the policy was applied at the same time when the demands of the labor wage increases and the input price increases. As a contra the increasing welfare of farm and non-farm household both in the village and in the city support the theory which state that the cost structure of production and marketing margins for domestic and imported commodities will affect the amount of household income and expenditure. Especially for the developing countries as Indonesia, where the majority of household income was used to buy main food. The improvement of agricultural marketing efficiency will directly effect on the decline in the trade and transport margins, so that the retail price of the commodity at the consumer level can be lower, which effect on the increasing consumer household purchasing power and household welfare.

\section{CONCLUSION}

Policy of agricultural marketing efficiency improvement by $5-15 \%$ have a positive effect on increasing the quantity of domestic output, export and import almost in all sectors, except for certain sector. The greater marketing efficiency improvement, the greater household expenditure. The finding show that improvement on marketing efficiency by $5-15 \%$, will increase the manufacturer expenditure by $40.6-44.8 \%$; household by $3.3-6.7 \%$; and government by $3.9-7.3 \%$.

Marketing efficiency improvement by $5 \%$ will improve the welfare of farm and non-farm household in the village and in the city by 0.69 to $0.93 \%$, while the producer welfare decline by $38.15 \%$. Furthermore, the improvement policy by $8-15 \%$, will increase the welfare of farm and non-farm households in the village and in the city by 0.86 to $1.12 \%$, and decrease producer welfare by 38.15 to $40.23 \%$. Thus, the greater marketing efficiency improvement, the greater household welfare but the smaller producer welfare.

According to the empirical result, government needs to: (1) develop a strategic action (regulation) to implement the marketing efficiency improvement strategies, (2) establish policies which support the production enlargement, (3) provide protection to agricultural products, by setting the import tariff of rice and import quotas, (4) reduce the dependence on rice consumption (5) control the market, by determination of the minimum wage policy (Regional Minimum Wage) and price stabilization policies.

Further research is recommended to use a dynamic CGE models which combine marketing policy and other government policies. The applied of static CGE models to measure the effects of agricultural marketing efficiency improvements on the distribution of household income and poverty are highly recommended. Thus, it can capture the effect of the policy improvements in marketing efficiency and long term effectiveness of marketing policy in Indonesia.

\section{ACKNOWLEDGEMENTS}

Thank you to the Directorate General of Higher Education, Ministry of Education and Culture of Indonesia, and the Rector of Brawijaya University which has been pleased to fund this study through University of Brawijaya DIPA funding, number: 0636/023-04.2.16/15/2012, dated December $9^{\text {th }}$ 2011, and based on Rector's Decree of University of Brawijaya No.419/SK/2012 dated September $27^{\text {th }}$ 2012. Hopefully the output of this study can enrich science field and enable to become a recommendation to the government's policy on agricultural development which referred to food security and household welfare. 


\section{REFERENCES}

[1] Arndt, Channing; Henning Tarp Jensen; Sherman Robinson and Finn Tarp. 1999. Marketing Margins and Agricultural Technology in Mozambique. Trade and Macroeconomics Division. International Food Policy Research Institute. Washington D.C, USA

[2] National Bureau of Statistic. 2010. Tabel Sistem Neraca Sosial Ekonomi Indonesia tahun 2008. Jakarta: BPS.

[3] Borton, J. And J. Shoham, 1991. Mapping Vulnerability to Food Insecurity: Tentative Guidelines for WFP Offices, Mimeo. Study Commisioned by the World Food Programme. London: Relief and Development Institute.

[4] Downey, W.D. dan S.P. Erickson, 2002. Agribusiness Management. Third Edition. McGraw-Hill.

[5] Hayami, Yujiro. 2001. Development Economics: From the Poverty to the Wealth of Nations. Second Edition. Oxford University Press.

[6] Janvry, Alan de. 1975. The Political Economy of Rural Development in Latin America: An Interpretation. American Jurnal of Agricultural Economics. Vol.57. No. 3 (Agustus 1975), pp. 490 - 499

[7] Landes dan Burfisher, 2009. Growth and Equity Effects of Agricultural Marketing Efficiency in India. United States Department of Agriculture. Economic Research Report No.88.

[8] Lofgren,H., Rebecca Lee Harris, Sherman Robinson. 2002. A Standard Computable General Equilibrium (CGE) Model in GAMS. International Food Policy Research Institute. Washington DC.

[9] Mapfumo, A., Mushunje, A. \& Chidoko, C. (2012). The Impact of Government Agricultural Expenditure on Poverty In Zimbabwe. Received June 27, 2012. Russian Journal of Agricultural and Socio-Economic Sciences. ISSN 2226-1184.

[10] Markusen, J R. 2005. Introduction to GAMS for Economic Euilibriums Problems. University of Colorado, Boulder, version July 4, 2005.

[11] Mellor, JW. 1967. Toward a Theory of Agricultural Development in Agriculture Development and Economic Growth. Edited by HS Southworth dan BF Johnston. Cornell University Press.

[12] Pudjiastuti, A.Q., Ratya Anindita, Nuhfil Hanani and David Kaluge. 2013. Changes Effect of Sugar Import Tariff in Indonesia. Russian Journal of Agricultural and SocioEconomic Sciences No 3(15), March 2013.

[13] Schultz, T. W. 1964. Transforming Traditional Agriculture, p. 5. New Haven: Yale University Press.

[14] Siregar, H dan Dwi Wahyuniarti.2007. Dampak Pertumbuhan Ekonomi Terhadap Penurunan Jumlah Penduduk Miskin. Article was presented in the national seminar on "Improving The Role of Agriculture Sector to Solve Poverty" in The Centre of Social Economic and Agriculture Policy Analysis., at Agustus $21^{\text {st }} 2007$.

[15] Smalley, EM dan Ehui,S . 1995. Livestock Policy Analysis. International Livestock Research Institute. Training Manual 2. ILRI, Nairobi, Kenya. pp. 264.

[16] Soudolet, Elizabeth and Alan de Janvry. 1995. Quantitave Development Policy Analysis. The Jhon Hopkins University Press.

[17] Weingartner, L. 2004. The Concept of Food and Nutrition Security in Klaus Klennert (ed). Achieving Food and Nutrition Security: Actions to Meet the Global Challenge. Bonn, Germany. 